\title{
Dyslipidemia Aterogenic, antara fakta dan harapan yang akan datang
}

\author{
Dianggan Sargowo
}

$\mathrm{D}$ isregulasi dari metabolisme lipoprotein merupakan inti dari perkembangan aterosklerosis. Suatu studi epidemi prospektif secara konsisten menunjukkan bahwa kenaikan dari Low Density Lipoprotein Cholesterol (LDL-C) dihubungkan dengan peningkatan risiko dari penyakit kardiovaskular, namun hal tersebut mungkin secara terpisah menyebabkan dislipidemia aterogenik, jika bergabung dengan hipertensi, obesitas sentral dan resistensi insulin, yang secara bersamaan dikenal sebagai sindroma metabolik. Dislipidemia aterogenik ditandai dengan tingginya trigliserid (TG) plasma, rendahnya High Density Lipoprotein Cholesterol (HDL-C) dan tingginya konsentrasi apolipoprotein (apo)-B yang berisi lipoprotein, khususnya peningkatan small dense LDL.

Hipertrigliserid (HTG) adalah peningkatan kadar trigliserid (TG) puasa di atas normal (> $150 \mathrm{mg} / \mathrm{dl}$ ). Pada 2010 di Amerika Serikat ada 74,6 juta penduduk mempunyai peningkatan kadar trigliserid, 36,4 juta diantara mereka memiliki kadar triglsierid yang tinggi (200-499 mg/dl), dengan meningkatnya prevalensi ini secara paralel juga terjadi peningkatan yang tajam terhadap kejadian obesitas. ${ }^{1}$

Penyebab peningkatan trigliserid secara umum adalah difisiensi lipoprotein lipase, chylomicronemia,

\section{Alamat Korespondensi}

Prof Dr. dr. Djanggan Sargowo, Sp.PD, Sp.JP(K), FIHA, FACC, FESC, FAPSC, FAsCC, Departemen Kardiologi dan Kedokteran Vaskular, FKUI dan Pusat Jantung Nasional Harapan Kita, Jakarta. E-mail: djanggan@yahoo.com
Tabel 1. Pembagian kadar trigliserid ${ }^{1}$

\begin{tabular}{ll}
\hline Level TG & $\mathrm{Mg} / \mathrm{dL}$ \\
\hline Normal Trigliserid & $<150$ \\
Borderline tinggi & $150-199$ \\
Tinggi & $200-499$ \\
Sangat tinggi & $>500$ \\
\hline
\end{tabular}

peningkatan kadar Very Low Density Lipoprotein (VLDL), penurunan kadar High Density Lipoprotein (HDL), dan adanya diabetes melitus type 1 dan type 2. Hipertrigliserid itu sendiri dapat dibagi menjadi dua tipe yaitu primer dan sekunder, akan tetapi dasar molekuler untuk hipertrigliserid primer telah ditemukan kurang dari 5\% kasus, dan untuk sekunder tidak ada kerentanan komponen genetik yang direproduksi. ${ }^{1,2}$

Pada studi case-control, trigliserid telah diketahui sebagai faktor risko dari penyakit kardiovaskular setelah penyesuaian dari kolesterol total atau HDL-C. Ada beberapa dasar bahwa kenaikan konsentrasi dari kadar trigliserid pada wanita lebih berisko daripada laki-laki. ${ }^{3}$

The Copenhagen City Heart Study pada tahun 2011 menunjukan bahwa peningkatan secara bertahap dari kadar kolesterol tidak puasa dan trigliserid tidak puasa mempunyai hubungan yang sama dengan peningkatan kejadian infark miokard, dimana pada trigliserid tidak puasa merupakan prediktor yang paling baik pada wanita dan kolesterol tidak puasa merupakan prediktor yang paling baik pada laki-laki. ${ }^{4,5}$

Hypertrigliserid terjadi melalui (1) produksi VLDL di hepar dan sintesis kilomikron di intestinal yang 
abnormal; (2) disfungsi LPL-mediated lipopylis; atau (3) gangguan sisa pembuangan. 3,6

Karena trigliserid dapat didegradasi oleh kebanyakan sel, akan tetapi kolestrol tidak dapat didegradasi oleh apapun, kandungan lipoprotein kolesterol yang kaya trigliserid (TRLs, Trigliserid-rich Lipoprotein) kemungkinan dapat menyebabkan aterosklerosis dan penyakit kardiovaskular. Penumpukan kolesterol pada intima yaitu bentuk foam cell dan plak aterosklerotik, seperti LDL dapat memasuki intima pembuluh darah, tetapi kilomikron terlalu besar untuk masuk. Aterogenik dari TRLs berhubungan dengan ukuran partikel sisa yang lebih kecil yang terakumulasi di dalam plasma mengikuti lipolisis dari kilomikron dan VLDL. Sisa TRLs lebih lanjut berkontribusi menjadi aterosklerosis dengan merusak fungsi endotel serta mengaktifkan monocytes dan jalur inflamasi. Mereka juga berefek secara langsung pada proses trombogenik dengan merangsang keluarnya faktor jaringan seluler dan trombin serta menghambat fibrinolisis. Ketika partikel sisa tidak hanya berisi TGs akan tetapi kira-kira empat puluh kali lebih besar kadar dari kolesterol ester per partikel dibandingkan dengan LDL, peningkatan ini dapat menyebabkan percepatan kejadian aterosklerosis dan penyakit kardiovaskular. ${ }^{4,6}$

Kadar LDL yang sangat tinggi ( $>500 \mathrm{mg} / \mathrm{dL}$ ) berhubungan dengan hipertrigliserid yang berat, dan hipertligiserid yang sangat berat (>2000 mg/ dL0 meningkatkan risiko akut pankreatitis, dimana hipertrigliserid ringan dan sedang merupakan faktor risiko untuk penyakit kardiovaskular. ${ }^{6}$

Studi prospektif mengindikasikan bahwa, dibandingkan antara kadar serum trigliserid puasa dan tidak puasa bisa menjadi prediktor yang lebih baik atau serupa untuk kejadian penyakit kardiovaskular pada populasi umum.

NCEP ATP III merekomendasikan tujuan pengobatan non-HDL kolesterol adalah sebagai target pengobatan sekunder dengan pasien dengan kadar TG $>200 \mathrm{mg} / \mathrm{dL}$ dengan target pengobatan utama adalah LDL kolesterol. Terdapat kesepatakan umum tentang perubahan gaya hidup, meliputi komposisi diit yang sesuai, aktifitas fisik dan penurunan berat badan adalah dasar untuk penanganan hipertrigliserid ringan sampai sedang. Pada beberapa kasus seperti pada kasus yang berat penambahan obat hypolipidemi mungkin dibutuhkan. Target utama dari pengobatan pada HTG yang berat adalah untuk menurunkan kadar TG dan mencegah pankreatitis.

Terapi farmakologi meliputi statin, fibrate, n-3 fatty acids dan niasin. Semuanya secara substansial dapat menurunkan kadar TG. Pendekatan secara rasional mungkin jika target utama adalah menurunkan kadar TG, fibrat dan n-3 fatty acid adalah yang terbaik. Di sisi lain, jika target utama adalah mengubah ukuran dan densitas dari partikel LDL dan HDL, niacin mungkin yang terbaik. Niacin juga mengurangi kinsentrasi lipoprotein dan faktor risiko independen kardiovaskular. Pengobatan statin menjadi biasa untuk pasien dengan peningkatan kadar kolesterol. ${ }^{7}$

Pada terapi kombinasi, penambahan fenofibrat pada statin dapat menurunkan kadar trigliserid, meningkatkan kadar HDL-C, mengurangi jumlah dari partikel small-dense LDL, yang kemudian menyebabkan perubahan pada ekspresi gen yang merubah metabolisme lemak.

Beberapa studi berskala besar telah memberi manfaat klinis dari terapi kombinasi antara statin dengan fenofibrat. Studi terbaru, sebuah meta-analisis dari lima placebo-controlled studies (ACCORD, FIELD [Fenofibrate Intercention and Event Lowering in Diabetes], BIP [Bezafibrate Inferction Prevention], HHS [Helsinki Herat Study], and VA-HIT [Veterans Affairs HDL Intervention Trial]) pada 4726 subjek dengan dislipedmia aterogenik, yang menyimpulkan bahwa penggunaan fibrat dihubungkan dengan penurunan dari risiko kejadian penyakit koroner sebesar 35\%.

The European Medicines Agency menyetujui fenofibrat sebagai terapi tambahan untuk meningkatkan peran diit dan penatalaksaan non-farmakologi lainnya (seperti olah raga, penurunan berat badan) dan untuk penanganan dari kondisi (1) HTG yang berat dengan atau tanpa kadar HDL yang rendah; (2) hiperlipidemi campuran ketika statin menjadi kontraindikasi atau intoleran; (3) hyperlipidemia campuran pada pasien dengan risiko tinggi CVD pada penambahan statin meski kadar TG dan HDL-C tidak bisa dikendalikan secara adekuat. ${ }^{6,7}$

\section{Daftar Pustaka}

1. Yuan G, Al-Shali KZ, Hegele RA. Hypertriglyceridemia: Its etiology, effect and treatment. Can Med Assoc J2007; 176:11131120 .

2. Balakumar P. Babbar L, Kalra S, Mahadevan N, Sritharan S, Krishan P. Is hypertriglyceridemia a key detrimental factor or associative triggering factor for cardiovascular abnormalities? Syst Rev Pharm 2012; 3:1-3. 
3. Nordestgaard BG, Varbo A. Triglycerides and cardiovascular disease. Lancet 2014; 384:626-635.

4. Boren J, Matikainen N, Adiels M, Taskinen MR. Postprandial hypertriglyceridemia as a coronary risk factor. Clinica Chimica Acta 2014; 431:131-142.

5. Watts GF, Karpe F. Why, when and how should hypertriglyceridemia be treated in the high risk cardiovascular patient? Expert
Rev Cardiovasc Ther 2011; 9:987-997.

6. Tenenbaum A, Klempfner R, Fisman EZ. Hypertriglyceridemia: A too long unfairly neglected major cardiovascular risk factor. Cardiovasc Diabetol 2014; 13: 159-168

7. Maki KC, Bays HE, Dicklin MR. Treatment options for the management of hypertriglyceridemia: Strategies based on the best available evidence. J Clin Lipidol 2012; 6:413-426. 